\title{
Pengaruh Perbandingan Terigu Dan Tepung Beras Merah (Oryza nivara) Terhadap Karakteristik Kue Lumpur
}

\author{
The Effect of Wheat Flour and Brown Rice Flour (Oryza nivara) Ratio \\ to The Characteristics of Lumpur Cake \\ Maureen Sabila*, I Ketut Suter, Putu Timur Ina \\ Program Studi Ilmu dan Teknologi Pangan, Fakultas Teknologi Pertanian, \\ Universitas Udayana, Jl. Raya Kampus Unud, Jimbaran, Kuta Selatan, Badung-Bali \\ Penulis korespondensi: Maureen Sabila, Email: maureensabila@gmail.com
}

\begin{abstract}
The research aims to determine the effect of wheat flour and brown rice flour ratio to the characteristics of lumpur cake and to know the right ratio from wheat flour and brown rice flour to produce lumpur cake with the best characteristics. The Completely Randomized Design was used in this research with the treatment ratio of wheat flour and brown rice flour which consisted of six levels, such as $100 \%$ : 0\%, 80\%: 20\%, 60\%: 40\%, 40\%:60\%, 20\%: 80\%, and 0\%: 100\%. Each treatments was repeated 3 times so that obtain 18 experiment units. The datas were analyzed by analysis of variance and if there were some effects of the treatment, the analysis followed by Duncan's Multiple Range Test. The result showed that wheat flour and brown rice flour ratio had some effects on water content, crude fiber content, anthocyanin content, antioxidant activity and color of lumpur cake. Ratio of $0 \%$ wheat flour and $100 \%$ brown rice flour had the best characteristics, with $53.21 \%$ water content, $7.61 \%$ crude fiber content, $20.20 \mathrm{mg} / 100 \mathrm{~g}$ anthocyanin content, $72.27 \%$ antioxidant activity, with sensory characteristics color and aroma liked, texture, taste and overall acceptance netral.
\end{abstract}

Keywords: Wheat flour, brown rice flour, characteristics, lumpur cake

\section{PENDAHULUAN}

Kue lumpur adalah salah satu kue khas Indonesia yang menjadi camilan favorit karena citarasanya manis, legit, dan teksturnya yang lembut (Sundoko, 2006). Kue lumpur yang bercitarasa original dibuat dari campuran terigu, gula pasir, telur dan santan. Biasanya bagian atas diberi isi yang terdiri dari potongan kelapa muda dan kismis (Muaris, 2004).

Berbagai variasi rasa kue lumpur dijual di pasaran, namun bahan baku yang digunakan tetap terigu (Hapsari, 2018). Meningkatnya permintaan untuk industri makanan dalam negeri membuat
Indonesia harus mengimpor gandum dari luar negeri. Volume impor gandum Indonesia pada tahun 2017 naik sekitar 9\% menjadi 11,48 juta ton dari tahun sebelumnya. Berdasarkan profil penggunaan gandum dalam negeri, sebesar $64 \%$ penggunaan gandum digunakan oleh industri kecil antara lain untuk pembuatan usaha bakery, biskuit, cake, hingga kue basah (Anon., 2017).

Impor gandum diharapkan dapat dikurangi dengan cara diversifikasi pangan pada pangan berbahan dasar terigu. Menurut Gafar (2009), diversifikasi pangan berbasis tepung lebih mudah diterima oleh masyarakat. Penggunaannya dalam 
bentuk tepung juga lebih fleksibel karena dapat dipakai sebagai bahan baku atau campuran (composite flour) dalam pembuatan roti, mi, jajan pasar seperti kue lumpur dan sebagainya.

Menurut Anon. (2009), kandungan gizi beras merah terdiri atas air 11,3 gram, protein 9,4 gram, vitamin B 3,3 gram, serat 4,6 gram, karbohidrat 72,2 gram dan energi 333,6 kkal. Berdasarkan hasil penelitian Forsalina (2009), penggunaan terigu dapat disubstitusi dengan tepung beras merah. Hasil penelitian tersebut yaitu dengan penggunaan tepung beras merah $25 \%$ pada bakpao menghasilkan aktivitas antioksidan tertinggi sebesar 48,43\%. Hasil penelitian lain oleh Dewi, dkk. (2016), yaitu dengan variasi pencampuran tepung beras merah $60 \%$ pada bolu kukus didapatkan hasil rata-rata kadar antosianin tertinggi sebesar 3,4621 ppm.

Berdasarkan pertimbangan tersebut, maka perlu dilakukan penelitian mengenai pengaruh perbandingan terigu dan tepung beras merah terhadap karakteristik kue lumpur. Penelitian ini diharapkan dapat meningkatkan kandungan nilai gizi kue lumpur dan menjadikan kue lumpur sebagai alternatif pangan fungsional.

\section{METODE PENELITIAN}

\section{Tempat dan Waktu}

Penelitian ini dilaksanakan di

Laboratorium Analisis Pangan, Laboratorium Pengolahan Pangan, Laboratorium Rekayasa Proses dan Pengendalian Mutu, serta Laboratorium Teknik Pasca Panen, Fakultas Teknologi Pertanian, Universitas Udayana. Penelitian ini dilakukan pada bulan Juli - Agustus 2019.

\section{Bahan dan Alat}

Bahan yang digunakan dalam penelitian ini adalah beras merah dari Desa Jatiluwih, Kabupaten Tabanan, Provinsi Bali, terigu (merek segitiga biru), margarin (merek blueband), telur, santan kental (merek kara) dan gula pasir putih (merek gulaku). Bahan-bahan kimia yang digunakan pada penelitian ini adalah 1,1Diphenyl-2-picryl Hidrazil (DPPH), metanol, $\mathrm{H}_{2} \mathrm{SO}_{4}$, heksan, aquades, $\mathrm{NaOH}$, alkohol 95\%, larutan buffer $\mathrm{pH} 1$, larutan buffer $\mathrm{pH}$ 4,5 dan $\mathrm{HCl}$.

Alat-alat yang digunakan dalam penelitian ini adalah kompor gas (Rinnai), blender (Advance), timbangan analitik (Shimadzu ATY224), baskom, pisau, sendok, cetakan kue lumpur, termometer, mikser (Miyako) dan ayakan 80 mesh (Sieve). Untuk analisis diperlukan alatalat : oven (Blue M), soxhlet (Behrotest), timbangan analitik (Shimadzu ATY224), botol kaca, vortex (Barnstead Thermolyne Type 37600 mixer), kertas saring, corong, labu ukur, tip, pipet mikro, gelas beker, cawan, alumunium foil, spektrofotometer (Genesys 10S Uv-Vis), tabung reaksi, kertas saring whatman no. 42 , erlenmeyer dan waterbath (Thermology).

\section{Rancangan Percobaan}

Rancangan yang digunakan pada penelitian ini adalah Rancangan Acak Lengkap (RAL) dengan perlakuan perbandingan terigu dan tepung beras merah yang terdiri dari 6 taraf yaitu : P0 = $100 \%: 0 \%, \mathrm{P} 1=80 \%: 20 \%, \mathrm{P} 2=60 \%: 40 \%, \mathrm{P} 3$ $=40 \%: 60 \%, \mathrm{P} 4=20 \%: 80 \%, \mathrm{P} 5=0 \%: 100 \%$. Masing-masing perlakuan diulang sebanyak $3 \mathrm{kali}$ sehingga diperoleh 18 unit percobaan. Data yang 
diperoleh dianalisis dengan sidik ragam dan apabila perlakuan berpengaruh terhadap variabel, maka dilanjutkan dengan uji Duncan (Steel dan Torrie, 1993).

\section{Pelaksanaan Penelitian}

\section{Pembuatan Tepung Beras Merah}

Pembuatan tepung beras merah diawali dengan beras merah disortir kemudian dihaluskan dengan blender. Selanjutnya diayak menggunakan ayakan 80 mesh.

\section{Persiapan Bahan}

Terigu, tepung beras merah, margarin yang sudah dipanaskan sampai mencair, santan kental, gula pasir putih, telur dan air mineral ditimbang sesuai formula yang sudah ditentukan. Adapun formula kue lumpur dapat dilihat pada Tabel 1.

Tabel 1. Formula kue lumpur (Anggrek, 2009) yang dimodifikasi

\begin{tabular}{|l|l|l|l|l|l|l|}
\hline \multirow{2}{*}{ Bahan } & \multicolumn{5}{|c|}{ Perlakuan } \\
\cline { 2 - 7 } & P0 & P1 & P2 & P3 & P4 & P5 \\
\hline Terigu (\%) & 100 & 80 & 60 & 40 & 20 & 0 \\
\hline $\begin{array}{l}\text { Tepung } \\
\text { beras } \\
\text { merah } \\
(\%)\end{array}$ & 0 & 20 & 40 & 60 & 80 & 100 \\
\hline $\begin{array}{l}\text { Santan } \\
(\%)\end{array}$ & 300 & 300 & 300 & 300 & 300 & 300 \\
\hline $\begin{array}{l}\text { Air } \\
\text { mineral } \\
(\%)\end{array}$ & 165 & 165 & 165 & 165 & 165 & 165 \\
\hline $\begin{array}{l}\text { Margarin } \\
(\%)\end{array}$ & 50 & 50 & 50 & 50 & 50 & 50 \\
\hline $\begin{array}{l}\text { Gula pasir } \\
(\%)\end{array}$ & 65 & 65 & 65 & 65 & 65 & 65 \\
\hline Telur (\%) & 165 & 165 & 165 & 165 & 165 & 165 \\
\hline
\end{tabular}

Keterangan : Persentase di atas berdasarkan jumlah terigu dan tepung beras merah $(100 \mathrm{~g})$

\section{Proses Pembuatan Kue Lumpur}

Tahap pembuatan kue lumpur diawali dengan dikocok telur dan gula pasir putih dengan mikser sampai mengembang. Dimasukkan santan kental, terigu dan tepung beras merah sesuai perlakuan, air mineral, dan margarin yang sudah dipanaskan hingga mencair ke dalam baskom, kemudian dikocok dengan mikser sampai homogen. Adonan dituangkan ke dalam cetakan kue lumpur yang sudah panas $\left(110^{\circ} \mathrm{C}\right)$ dan diolesi margarin, kemudian cetakan ditutup. Adonan dimasak sampai matang selama 15 menit lalu kue lumpur diangkat.

\section{Variabel yang Diamati}

Variabel yang diamati pada penelitian ini meliputi kadar air metode pengeringan (Sudarmadji dkk., 1997), aktivitas antioksidan metode DPPH (Sompong dkk., 2011), total antosianin metode $\mathrm{pH}$ differensial (Giusti dan Worlstad, 2001), kadar serat kasar metode hidrolisis asam dan basa (Sudarmadji dkk., 1989) dan sifat sensoris dengan uji hedonik pada warna, aroma, tekstur, rasa dan penerimaan keseluruhan (Soekarto, 1995).

\section{HASIL DAN PEMBAHASAN}

Hasil analisis kadar air, kadar serat kasar, kadar antosianin dan aktivitas antioksidan terigu dan tepung beras merah dapat dilihat pada Tabel 2. Hasil analisis kadar air, kadar serat kasar, kadar antosianin dan aktivitas antioksidan pada kue lumpur dengan perlakuan perbandingan terigu dan tepung beras merah dapat dilihat pada Tabel3 
Tabel 2. Nilai rata-rata kadar air, kadar serat kasar, kadar antosianin dan aktivitas antioksidan terigu dan tepung beras merah

\begin{tabular}{lcc}
\hline \multirow{2}{*}{ Parameter } & \multicolumn{2}{c}{ Bahan } \\
\cline { 2 - 3 } & Terigu & Tepung beras merah \\
\hline Kadar air $(\%)$ & 12,18 & 12,63 \\
Kadar serat kasar (\%) & 0,69 & 4,35 \\
Kadar antosianin (mg/100g) & 0,00 & 28,51 \\
Aktivitas antioksidan $(\%)$ & 4,33 & 91,35 \\
\hline
\end{tabular}

Tabel 3. Nilai rata-rata kadar air, kadar serat kasar, kadar antosianin dan aktivitas antioksidan pada kue lumpur dengan perlakuan perbandingan terigu dan tepung beras merah.

\begin{tabular}{ccccc}
\hline $\begin{array}{c}\text { Perlakuan } \\
\text { (Terigu : Tepung } \\
\text { Beras Merah) }\end{array}$ & Kadar Air (\%) & $\begin{array}{c}\text { Kadar Serat } \\
\text { Kasar } \\
(\%)\end{array}$ & $\begin{array}{c}\text { Kadar Antosianin } \\
(\mathrm{mg} / 100 \mathrm{~g})\end{array}$ & $\begin{array}{c}\text { Aktivitas } \\
\text { Antioksidan }(\%)\end{array}$ \\
\hline P0 $(100 \%: 0 \%)$ & $55,85 \pm 0,065 \mathrm{a}$ & $5,01 \pm 0,022 \mathrm{f}$ & $0,00 \pm 0,000 \mathrm{f}$ & $5,75 \pm 0,185 \mathrm{f}$ \\
P1 $(80 \%: 20 \%)$ & $55,61 \pm 0,062 \mathrm{a}$ & $5,46 \pm 0,052 \mathrm{e}$ & $7,36 \pm 0,175 \mathrm{e}$ & $19,76 \pm 0,164 \mathrm{e}$ \\
P2 $(60 \%: 40 \%)$ & $55,21 \pm 0,125 \mathrm{~b}$ & $5,76 \pm 0,042 \mathrm{~d}$ & $9,77 \pm 0,135 \mathrm{~d}$ & $35,26 \pm 0,369 \mathrm{~d}$ \\
P3 $(40 \%: 60 \%)$ & $54,61 \pm 0,305 \mathrm{c}$ & $6,53 \pm 0,024 \mathrm{c}$ & $15,06 \pm 0,117 \mathrm{c}$ & $48,25 \pm 0,772 \mathrm{c}$ \\
P4 $(20 \%: 80 \%)$ & $53,54 \pm 0,086 \mathrm{~d}$ & $7,22 \pm 0,089 \mathrm{~b}$ & $17,28 \pm 0,546 \mathrm{~b}$ & $66,92 \pm 0,695 \mathrm{~b}$ \\
P5 $(0 \%: 100 \%)$ & $53,21 \pm 0,017 \mathrm{e}$ & $7,61 \pm 0,022 \mathrm{a}$ & $20,20 \pm 0,445 \mathrm{a}$ & $72,27 \pm 0,892 \mathrm{a}$ \\
\hline
\end{tabular}

Keterangan : Huruf yang sama di belakang nilai rata-rata pada kolom yang sama menunjukkan perlakuan berbeda tidak nyata $(\mathrm{P}>0,05)$

\section{Kadar Air}

Hasil sidik ragam menunjukkan bahwa perbandingan terigu dan tepung beras merah berpengaruh nyata $(\mathrm{P}<0,05)$ terhadap kadar air kue lumpur. Tabel 3 menunjukkan nilai rata-rata kadar air kue lumpur berkisar antara 53,21\% sampai dengan $55,85 \%$. Nilai rata-rata kadar air tertinggi kue lumpur terdapat pada perlakuan P0 yaitu $55,85 \%$ serta berbeda tidak nyata dengan perlakuan P1, sedangkan nilai rata-rata kadar air terendah terdapat pada perlakuan P5 yaitu $53,21 \%$. Semakin tinggi perbandingan tepung beras merah maka kadar air kue lumpur semakin menurun. Penurunan kadar air kue lumpur dapat terjadi karena tepung beras merah tidak memiliki kandungan gluten seperti terigu.
Terigu mengandung protein yang dikenal sebagai gluten yang dibentuk dari gliadin dan glutenin. Glutenin memiliki fungsi dalam pembentukan volume air (Desrosier, 1988), karena glutenin bersifat menyerap air sehingga semakin sedikit penambahan terigu maka semakin rendah kadar air kue lumpur. Hasil yang sama juga didapatkan oleh Forsalina (2009), yaitu semakin tinggi substitusi tepung beras merah maka kadar air bakpao semakin menurun.

Penurunan kadar air pada kue lumpur juga dapat disebabkan karena adanya perbedaan kadar amilosa pada bahan. Beras merah memiliki kadar amilosa yang lebih tinggi dari terigu. Menurut Hartika (2009), 
semakin banyak kadar amilosa, maka kadar air bahan akan menurun karena semakin banyak air yang diikat dan dilepas oleh pati di dalam adonan. Kadar amilosa beras merah sebesar 28,14 33,21\% (Lalel dkk., 2009), sedangkan pada terigu sebesar 25\% (Muchtadi, 2011). Rahmah, dkk. (2017) menjelaskan, daya serap air dipengaruhi oleh kadar amilosa. Amilosa mudah untuk mengikat dan melepas air karena memiliki struktur lurus dan banyak mengandung gugus hidroksil.

\section{Kadar Serat Kasar}

Hasil sidik ragam menunjukan perbandingan terigu dan tepung beras merah berpengaruh nyata $(\mathrm{P}<0,05)$ terhadap kadar serat kasar kue lumpur. Tabel 3 menunjukkan nilai ratarata kadar serat kasar kue lumpur berkisar antara $5,01 \%$ sampai dengan $7,61 \%$. Nilai rata-rata kadar serat kasar tertinggi terdapat pada perlakuan P5 yaitu $7,61 \%$ dan nilai rata-rata kadar serat kasar terendah terdapat pada perlakuan P0 yaitu 5,01\%. Data tersebut menunjukkan bahwa semakin banyak penambahan tepung beras merah, maka kadar serat kasar kue lumpur semakin meningkat. Peningkatan kadar serat kasar kue lumpur dapat disebabkan karena adanya perbedaan kadar serat kasar pada bahan baku yang dapat dilihat pada Tabel 4, yaitu kadar serat kasar tepung beras merah lebih tinggi dari terigu. Hasil yang sama juga didapatkan pada penelitian Hariati, dkk. (2018), yaitu pada produk bolu kukus perlakuan $100 \%$ terigu mengandung serat kasar 2,27\%, sedangkan dengan perlakuan perbandingan $50 \%$ terigu dan $50 \%$ tepung beras merah dapat meningkatkan kadar serat kasar produk bolu kukus menjadi 4,23\%.

\section{Kadar Antosianin}

Hasil sidik ragam menunjukan bahwa perbandingan terigu dan tepung beras merah berpengaruh nyata $(\mathrm{P}<0,05)$ terhadap kadar antosianin kue lumpur. Tabel 3 menunjukkan nilai rata-rata kadar antosianin kue lumpur berkisar antara $\quad 0,00 \mathrm{mg} / 100 \mathrm{~g}$ sampai dengan 20,20mg/100g. Nilai rata-rata kadar antosianin tertinggi terdapat pada perlakuan P5 yaitu 20,20mg/100g dan nilai rata-rata kadar antosianin terendah terdapat pada perlakuan P0 yaitu 0,00mg/100g. Berdasarkan data tersebut, semakin banyak penambahan tepung beras merah maka kadar antosianin kue lumpur semakin meningkat. Peningkatan kadar antosianin kue lumpur dapat disebabkan karena adanya perbedaan kadar antosianin pada bahan baku yang dapat dilihat pada Tabel 2, yaitu kadar antosianin tepung beras merah lebih tinggi dari terigu. Menurut Suda (2003), bahan makanan yang memiliki warna merah, ungu dan kehitaman dilaporkan memiliki kandungan pigmen antosianin yang tinggi. Chang dan Berdenas (1965) menambahkan, pigmen antosianin pada beras merah terdapat pada kulit beras dan juga meliputi seluruh bagian beras. Menurut Wang, dkk. (1997), antosianin termasuk komponen flavonoid, yaitu turunan polifenol pada tumbuhan yang bermanfaat sebagai antioksidan, mencegah penyempitan pembuluh arteri dan antikanker. 


\section{Aktivitas Antioksidan}

Hasil sidik ragam menunjukan bahwa perbandingan terigu dan tepung beras merah berpengaruh nyata $(\mathrm{P}<0,05)$ terhadap aktivitas antioksidan kue lumpur. Tabel 3 menunjukkan nilai rata-rata aktivitas antioksidan kue lumpur berkisar antara 5,75\% sampai dengan $72,27 \%$. Nilai rata-rata aktivitas antioksidan tertinggi terdapat pada perlakuan P5 yaitu 72,27\% dan nilai rata-rata aktivitas antioksidan terendah terdapat pada perlakuan P0 yaitu $5,75 \%$. Data tersebut menunjukkan bahwa semakin banyak penambahan tepung beras merah maka aktivitas antioksidan kue lumpur semakin meningkat. Menurut penelitian Azis, dkk. (2015), tingginya aktivitas antioksidan pada beras merah disebabkan oleh banyaknya kandungan pigmen antosianin yang berperan sebagai antioksidan.

\section{Sifat Sensoris}

Sifat sensoris kue lumpur dilakukan dengan uji hedonik terhadap warna, aroma, tekstur, rasa dan penerimaan keseluruhan. Nilai rata-rata sifat sensoris kue lumpur dengan perlakuan perbandingan terigu dan tepung beras merah dapat dilihat pada Tabel 4.

\section{Warna}

Hasil sidik ragam menunjukkan bahwa perbandingan terigu dan tepung beras merah berpengaruh nyata $(\mathrm{P}<0,05)$ terhadap kesukaan warna kue lumpur. Tabel 4 menunjukkan bahwa nilai rata-rata kesukaan panelis terhadap warna berkisar antara 3,13 (biasa) sampai dengan 3,87 (suka). Nilai rata-rata kesukaan warna tertinggi kue lumpur terdapat pada perlakuan P5 yaitu 3,87 (suka) serta berbeda tidak nyata dengan perlakuan P0, P2, P3 dan P4, sedangkan nilai rata-rata kesukaan warna terendah terdapat pada perlakuan P1 yaitu 3,13 (biasa) serta berbeda tidak nyata dengan perlakuan P2 dan P3. Hasil ini menunjukkan bahwa perbandingan terigu dan tepung beras merah menghasilkan kue lumpur dengan warna biasa sampai suka.

\section{Aroma}

Hasil sidik ragam menunjukkan bahwa perbandingan terigu dan tepung beras merah berpengaruh tidak nyata $(\mathrm{P}>0,05)$ terhadap kesukaan aroma kue lumpur. Tabel 4 menunjukkan bahwa nilai rata-rata kesukaan panelis terhadap aroma kue lumpur berkisar antara 3,87 (suka) sampai dengan 4 (suka). Hasil ini menunjukkan bahwa perbandingan terigu dan tepung beras merah menghasilkan kue lumpur dengan aroma yang disukai.

\section{Tekstur}

Hasil sidik ragam menunjukkan bahwa perbandingan terigu dan tepung beras merah berpengaruh tidak nyata $(\mathrm{P}>0,05)$ terhadap kesukaan tekstur kue lumpur. Tabel 4 menunjukkan bahwa nilai rata-rata kesukaan panelis terhadap kesukaan tekstur kue lumpur berkisar antara 3,33 (biasa) sampai dengan 4,07 (suka). Hasil ini menunjukkan bahwa perbandingan terigu dan tepung beras merah menghasilkan kue lumpur dengan tekstur biasa sampai suka. 
Tabel 4. Nilai rata-rata sifat sensoris kue lumpur dengan perlakuan perbandingan terigu dan tepung beras merah

\begin{tabular}{cccccc}
\hline $\begin{array}{c}\text { Perlakuan } \\
\begin{array}{c}\text { Terigu : Tepung Beras } \\
\text { Merah) }\end{array}\end{array}$ & Warna & Aroma & Tekstur & Rasa & $\begin{array}{c}\text { Penerimaan } \\
\text { keseluruhan }\end{array}$ \\
\hline P0 $(100 \%: 0 \%)$ & $3,80 \mathrm{a}$ & $4,00 \mathrm{a}$ & $4,07 \mathrm{a}$ & $3,87 \mathrm{a}$ & $3,60 \mathrm{a}$ \\
P1 $(80 \%: 20 \%)$ & $3,13 \mathrm{~b}$ & $3,93 \mathrm{a}$ & $4,00 \mathrm{a}$ & $3,87 \mathrm{a}$ & $3,80 \mathrm{a}$ \\
P2 $(60 \%: 40 \%)$ & $3,47 \mathrm{ab}$ & $3,87 \mathrm{a}$ & $3,80 \mathrm{a}$ & $4,13 \mathrm{a}$ & $3,87 \mathrm{a}$ \\
P3 $(40 \%: 60 \%)$ & $3,60 \mathrm{ab}$ & $3,87 \mathrm{a}$ & $3,80 \mathrm{a}$ & $4,00 \mathrm{a}$ & $4,07 \mathrm{a}$ \\
P4 $(20 \%: 80 \%)$ & $3,87 \mathrm{a}$ & $4,00 \mathrm{a}$ & $3,73 \mathrm{a}$ & $3,80 \mathrm{a}$ & $4,00 \mathrm{a}$ \\
P5 $(0 \%: 100 \%)$ & $3,87 \mathrm{a}$ & $4,00 \mathrm{a}$ & $3,33 \mathrm{a}$ & $3,40 \mathrm{a}$ & $3,40 \mathrm{a}$ \\
\hline
\end{tabular}

Keterangan : Huruf yang sama di belakang nilai rata-rata pada kolom yang sama menunjukkan perlakuan berbeda tidak nyata $(\mathrm{P}>0,05)$

\section{Rasa}

Hasil sidik ragam menunjukkan bahwa perbandingan terigu dan tepung beras merah berpengaruh tidak nyata $(\mathrm{P}>0,05)$ terhadap kesukaan rasa kue lumpur. Tabel 4 menunjukkan bahwa nilai rata-rata kesukaan panelis terhadap kesukaan rasa kue lumpur berkisar antara 3,40 (biasa) sampai dengan 4,13 (suka). Hasil ini menunjukkan bahwa perbandingan terigu dan tepung beras merah menghasilkan kue lumpur dengan rasa biasa sampai suka.

\section{Penerimaan Keseluruhan}

Hasil sidik ragam menunjukkan bahwa perbandingan terigu dan tepung beras merah berpengaruh tidak nyata $(\mathrm{P}>0,05)$ terhadap penerimaan keseluruhan kue lumpur. Tabel 4 menunjukkan bahwa nilai rata-rata kesukaan panelis terhadap penerimaan keseluruhan kue lumpur berkisar antara 3,40 (biasa) sampai dengan 4,07 (suka). Hasil ini menunjukkan bahwa produk kue lumpur dengan perbandingan terigu dan tepung beras merah pada penelitian ini dapat diterima dengan cukup baik oleh panelis.

\section{KESIMPULAN DAN SARAN}

\section{Kesimpulan}

Berdasarkan hasil dan pembahasan penelitian maka dapat disimpulkan sebagai berikut.

1. Perbandingan terigu dan tepung beras merah berpengaruh sangat nyata terhadap kadar air, kadar serat kasar, kadar antosianin dan aktivitas antioksidan, berpengaruh nyata terhadap warna.

2. Perbandingan $0 \%$ terigu dan $100 \%$ tepung beras merah menghasilkan karakteristik terbaik dengan kadar air 53,21\%, kadar serat kasar 7,61\%, kadar antosianin 20,20 mg/100g, aktivitas antioksidan 72,27\%, warna dan aroma dengan kriteria suka, serta tekstur, rasa dan penerimaan keseluruhan dengan kriteria biasa.

\section{Saran}

Berdasarkan penelitian yang telah dilakukan, dapat disarankan untuk melakukan penelitian lebih lanjut dengan menambahkan bahan lain agar tekstur lebih lembut dan rasa semakin disukai sehingga dapat meningkatkan penerimaan keseluruhan dan menambah daya tarik terhadap produk kue lumpur. 


\section{DAFTAR PUSTAKA}

Anggrek, T. D. 2009. 500 Resep Lezat Selera Nusantara. Pustaka Anggrek, Yogyakarta.

Anonimus. 2009. Direktorat Gizi Departemen Kesehatan Republik Indonesia : Daftar Komposisi Bahan Makanan.

Anonimus. 2017. Badan Pusat Statistik : Volume dan Nilai Impor Gandum Indonesia(20122017).

https://databoks.katadata.co.id/datapublish/ 2018/02/

22/berapa-imporgandum-indonesia. Diakses pada tanggal 7 Mei 2019.

Azis, A., M. Izzati, dan S. Haryanti. 2015. Aktivitas antioksidan dan nilai gizi dari beberapa jenis beras dan millet sebagai bahan pangan fungsional indonesia. Jurnal Akademika Biologi, 4(1):45-61.

Chang, T. T. and E. A. Bardenas, 1965. The morphology and varietals characteristics of the rice plant, Tech. Bull. IRRI $4: 40$ pp.

Desrosier, N. W. 1988. Teknologi Pengawetan Pangan. Penerjemah Muchji Muljohardjo. UI-Press. Jakarta.

Forsalina, F., K. A. Nocianitri., dan I. D. K. Pratiwi. 2009. Pengaruh subtitusi terigu dengan tepung beras merah (Oryza nivara) terhadap karakteristik bakpao. Fakultas Teknologi Pertanian, Universitas Udayana, Bali.

Gafar, S. 2009. Diversifikasi pangan berbasis tepung: belajar dari pengelolaan kebijakan terigu. Artikel Pangan. Ed. 56:18.

Giusti, M. M. dan R. E. Worlstad. 2001. Characterization and Measurement of Anthocyanins by UV-Visible Spectroscopy. Oregon State University.

Hapsari, A. P. 2018. Pengaruh proporsi bahan utama (puree kacang merah dan tepung terigu), dengan puree ubi madu terhadap sifat organoleptik kue lumpur. Univeristas Negeri Surabaya. 7(2).

Hariati, N. Ansharullah dan N. Asyik. 2018. Pengaruh penambahan tepung beras merah (Oryza nivara L.) Terhadap uji organoleptik dan proksimat bolu kukus. Jurnal Sains dan Teknologi Pangan. 3 (1): 1006-1017.
Hartika, W. 2009. Kajian sifat fisik dan kimia tepung biji nangka (Artocarpus heterophyllus Lamk) dan aplikasinya dalam pembuatan roti manis. Skripsi. Universitas Andalas, Padang.

Lalel, H. J. D., Z. Abidin dan L. Jutomo. 2009. Sifat fisiko kimia beras merah gogo lokal ende. Jurnal teknologi dan Industri Pangan. 20(2).

Muaris, H. 2004. Seri Makanan Favorit : Kue Lumpur. www.bukabuku.com. Diakses tanggal 7 Mei 2019.

Muchtadi, T. R. dan F. A. Sugiyono. 2010. Ilmu Pengetahuan Bahan Pangan. Alfabeta, Bogor.

Nurani, S., dan S. S. Yuwono. 2014. Pemanfaatan tepung kimpul (Xanthosoma sagittifolium) sebagai bahan baku cookies (kajian proporsi tepung dan penambahan margarin). Jurnal Pangan dan Agroindustri. 2(2):50-58.

Sarofa, U., R. Yulistiani dan Wijaya R. 2012. Pemanfaatan tepung beras merah dalam pembuatan roti manis sebagai upaya pengurangan penggunaan tepung terigu. UPN "Veteran" Jawa Timur.

Soekarto, S. T. 1985. Penilaian Organoleptik (untuk Industri Pangan dan Hasil Pertanian). Bharata Karya Aksara, Jakarta.

Sompong, R., S. Siebenhandl-Ehn, G. LinsbergerMartin, and E. Berghofer. 2011. Physicochemical and Antioxidative Properties of Red and Black Rice Varieties from Thailand, China and Sri Lanka. Elsevier Appl. Schi. Pbl., 124, 132-140.

Steel, R. G. D. dan J. H. Torrie. 1993. Prinsip dan Prosedur Statistika suatu Pendekatan Biometrik. Penerjemah B. Sumantri. PT. Gramedia Pustaka, Jakarta.

Suda, I., T. Oki, M. Masuda, M. Kobayashi,Y. Nishiba, and S. Furuta. 2003. Physiological functionality of purple fleshed sweet potatoes containing anthocyanins and their utilization in foods. JARQ 37(3): 167-173.

Sudarmadji, S., B. Haryono dan Suhardi. 1989. Analisa Bahan Makanan dan Pertanian. Liberty, Yogyakarta. 
Sudarmadji, S., B. Haryono dan Suhardi. 1997. Analisa Bahan Makanan dan Hasil Pertanian. Gramedia Pustaka Utama, Jakarta.

Sundoko, L. S. 2006. Seri Kue Basah Favorit : Kue Lumpur Aneka Rasa. PT Gramedia Pustaka Utama, Jakarta.
Wang, G., B. Parpia, and Z. Wen. 1997. The composition of Chinese foods. Institute of Nutrition and Food Hygiene Chinese Academy of Preventive Medicine. Washington DC: ILSI Press. 